\title{
Biochemical Changes in Induced Caecal Coccidiosis in Broiler Birds Given Different Feed Anticoccidials at Anand, Gujarat, India
}

\author{
N.D. Hirani*, J.J. Hasnani, S.S. Pandya and S.P. Madhira \\ Dept. of Veterinary Parasitology, College of Veterinary Science \& AH, \\ Anand Agricultural University, Anand-388001, Gujarat, India \\ *Corresponding author
}

\section{A B S T R A C T}

\begin{tabular}{|l|}
\hline Key w or d s \\
Coccidiostats, \\
Salinomycin, \\
Biochemical, \\
Caecal coccidiosis, \\
Broiler, SGOT, \\
SGPT \\
\hline Article Info \\
\hline Accepted: \\
08 June 2018 \\
Available Online: \\
10 July 2018 \\
\hline \hline
\end{tabular}

Studies on biochemical profile revealed significantly $(\mathrm{P}<0.05)$ lower serum glucose and serum total protein, while significant increase in serum total cholesterol, Serum Glutamic Oxalo-acetic Transaminase (SGOT), Serum Glutamic Pyruvic Transaminase (SGPT) and Alkaline Phosphatase (AKP) activities was observed due to coccidial infection as compared to pre infection levels in birds. Biochemical studies indicated comparative less pathological damage by coccidiostats treatment as compared to infected non treated group, but there was no consistent trend for drug choice. Serum glucose values indicated better efficacy of D+S group as compare to Salinomycin and Maduramicin, results of serum total protein indicate better efficacy of Salinomycin, while serum total cholesterol results indicated better efficacy of Maduramicin and Diclazuril in all four treatment group. Serum Glutamic Oxalo-acetic Transaminase (SGOT) showed better efficacy of Salinomycin followed by Maduramicin as compared to Diclazuril and Diclazuril + Salinomycin group, Serum Glutamic Pyruvic Transaminase (SGPT) showed better efficacy of Diclazuril and Salinomycin and Serum Alkaline Phosphatase (AKP) indicated better efficacy of Salinomycin and Maduramicin as compared with Diclazuril and Diclazuril + Salinomycin group.

\section{Introduction}

Poultry meat constitutes around $20 \%$ of total meat production in the country (Singh, 2012). The per capita availability of poultry meat is $2.15 \mathrm{~kg} /$ annum which is very less as against the recommendation of $11 \mathrm{~kg}$ meat/annum given by National Institute of Nutrition (Prabhakaran, 2012). Hence, there is tremendous scope for further development in poultry meat sector. Challenges from bacteria, viruses and parasites placed a limit on production potential and high mortality was often noticed at the farms. Poultry sector is still confronted with many enteric diseases like coccidiosis which are hindering its progress (Saima et al., 2010). It is a disease which accounts for 5-10 per cent mortality rate of chickens and an unknown loss due to reduced weight gain and feed efficiency, damage to the digestive tract, decreased egg production and lowered resistance of birds to 
other poultry diseases. This disease is one of the most prevalent significant problems in poultry throughout the tropical countries (Chakrabarti, 1989) and the annual worldwide loss due to coccidiosis was estimated about $\$$ 800 million (Williams, 1998). The lesions caused by the parasite disturb nutrient absorption, triggering several changes in carbohydrates, lipid, protein and mineral metabolism (Patra et al., 2010). It produces deviation in the biochemical components of the body (McDougald and Reid, 1991; Deger et al., 2002.; Patra et al., 2010). In the organism, enzyme action is influenced by metabolic activities and pathologic condition. To combat clinical and subclinical forms of poultry diseases, accurate and differential diagnosis of the diseases at early stages of infections is necessary (Talebi et al., 2005). In broiler production, numerous anticoccidial drugs are used for prevention and control of coccidiosis. However, development of tolerance to these drugs have lead to search for newer molecules and different classes of anticoccidials have been discovered and used from time to time for prevention and control of coccidiosis. The knowledge of biochemical parameters will also help in diagnosis and control of coccidiosis in this area. So the comparative study of coccidiostat in broiler by giving experimental infection of E. tenella is planned to study the alteration in biochemical parameters.

\section{Materials and Methods}

The efficacy of three commonly used feed coccidiostats named Diclazuril (T1) Salinomycin (T2), Diclazuril + Salinomycin (T3) in shuttle programme and Maduramicin (T4) on experimentally induced Eimeria tenella coccidial infection and their effects on biochemical changes were undertaken in three hundred Cobb400 strain of broiler at University Poultry Complex, Anand Agricultural University, Anand during year
2012. Birds were given feed containing Diclazuril (T1), Salinomycin (T2), and Maduramicin (T4) coccidiostats at dose rate of 1 ppm, 60 ppm and 5 ppm upto 42 days. Experimental infection of 50,000 oocysts of E.tenella was given on $22^{\text {nd }}$ day of age. Blood was collected before experimental infection at 3 weeks and after experimental infection at 4 weeks of age for biochemical study.

Approximately $4 \mathrm{ml}$ of blood was collected from wing vein for separation of serum. Blood sample will be taken randomly from 10 birds in each group before experimental infection of $E$. tenella at 3 weeks and at 4 weeks of age after experimental infection of E. tenella with same group birds. Serum samples were stored at $-20^{\circ} \mathrm{C}$ in deep-freeze until analyzed for the biochemical and enzymatic attributes. In all, 60 blood samples before experimental infection and 60 blood samples after experimental infection of six groups of broilers were used for biochemical alterations. Estimation of serum glucose, Serum total protein and serum total cholesterol were carried out as per the Glucose Oxidase and Peroxidase (GOD/ POD), Biuret and Cholesterol Oxidase (CHOD) Methods, respectively by using kits of Crest Biosystems India Ltd., Goa.

Serum Glutamic Oxalo-acetic Transaminase (SGOT) and Serum Glutamic Pyruvic Transaminase (SGPT) were estimated by modified International Federation of Clinical Chemistry (IFCC) method (1986), while Serum Alkaline Phosphatase (AKP) activity was estimated by P- Nitro Phenyl phosphate (PNPN) method (1954) using kits of Crest Biosystems India Ltd., Goa, and the values were expressed as U/L. Data so generated were statistically analyzed as per the method of Snedecor and Cochran (1980) by using completely randomized design on SAS software version 2000. 


\section{Results and Discussion}

Coccidia can produce subtle change in metabolism. In disease condition, enzyme action is also influenced by metabolic activities (Allen, 1988). The result of serum biochemical and enzymatic profile in different coccidiostat treatment before and after experimental infection are presented in Table 1 and 2.

\section{Effects on serum glucose}

Before experimental infection at 3 weeks of age, serum glucose values were more or less similar in treatment as well as in control group. After experimental infection there was significant reduction in glucose value. The highest reduction (mg \%) was observed in T2 group $(210.40 \pm 1.63)$ followed by $\mathrm{T} 4$ group $(224.20 \pm 5.05)$, $\mathrm{T} 1$ group $(237.40 \pm 1.58)$ and T3 group (238.40 \pm 1.36$)$. T5 positive control group had shown significant lower post infection glucose value $(203.60 \pm 2.73 \mathrm{mg} \%)$ as compare to pre infection control value $(267.90 \pm 2.58 \mathrm{mg} \%)$. Results indicates better efficacy of Diclazuril + Salinomycin group as compare to Salinomycin and Maduramicin in relation to effect on glucose.

Pangasa et al., (2007) reported significant low glucose in infected and non medicated broilers as compared to control and Salinomycin coccidiostat fed broilers given 50,000 oocyst of $E$. tenella during acute phase of disease. Salinomycin had given better result with less glucose reduction similar to our findings. Reduction in glucose might be due to defect in absorption of glucose, leakage of glucose in plasma and increase demand of glucose by developing stage of parasite as reported by Mondal et al., (2011). Padmavathi and Muralidharam (1986) who recorded hypoglycaemia with 50,000 E.tenella oocysts infection at 7 day PI and Constantinescu (1976) found hypoglycaemia in mixed infection, and Freeman (1970) and Basith et al., (2000) failed to see any change in plasma glucose.

\section{Effect on serum total protein}

Serum Total Protein Value are more or less similar in treatment group at 3 week of age, but it was significantly reduced after experimental infection. Highest decrease in serum protein value ( $\mathrm{g} \%$ ) observe in T4 group (3.46 \pm 0.08$)$ followed by $\mathrm{T} 1$ group (3.58 \pm $0.08)$, T3 group $(3.62 \pm 0.07)$ and $\mathrm{T} 2$ group $(3.75 \pm 0.03)$. Post infection value of positive control was significant lower $(3.28 \pm 0.06 \mathrm{~g}$ $\%)$ as compared to pre infection $(4.62 \pm 0.06 \mathrm{~g}$ $\%)$. Result indicated better efficacy of Salinomycin among four treatments. The study revealed that there was significant reduction in levels of serum protein among the infected birds. Infected birds had hypoproteinaemia from Day 7 Day PI.

Mondal et al., (2011) reported decrease in Protein in broilers given 20000-25000 doses of E.tenella oocysts infection. They also stated that protein decrease is due to rapid movement of interstitial fluid without protein into the plasma and also due to acute stress responsible for cortisol secretion and disturbances in protein catabolism.

Padmavathi and Muralidharan (1986) and Conway et al., (1993) who all recorded lowered total serum protein values in $E$. tenella infected birds. The significant reduction in serum total protein observed in affected birds might be due to reduced feed intake and/or haemorrahges through the gut leads reduced absorption of amino acids and formation of inflammatory exudates rich in blood proteins (Basith et al., 2000). It might also be due to decreased retention and change in the protein metabolism (Conway et al., 1993). 


\section{Effect on serum total cholesterol}

Before experimental infection at 3 week of age, serum total cholesterol values were more or less similar except Maduramicin group. This T4 group showing significantly higher serum total cholesterol values $(119.40 \pm 1.19$ mg \%). After experimental infection of E.tenella serum total cholesterol value were significant increases in control as were as treatment group. Higher Serum cholesterol values $(\mathrm{mg} \%)$ were observed in T3 shuttle group (131.90 \pm 3.12$)$ followed by $\mathrm{T} 2$ group $(130.50 \pm 3.58)$, T1 group (121.60 \pm 0.65$)$ and T4 group (122.00 \pm 0.60$)$ in post infection treatment group. Positive control T5 group shown significant high post infection value $(142.50 \pm 1.44 \mathrm{mg} \%)$, as compare to pre infection value $(112.80 \pm 2.37 \mathrm{mg} \%)$. Result indicate better efficacy of Maduramicin in all four treatment group at four week of age. Mondal et al., (2011) reported increase in cholesterol value in broilers given 2000025000 doses of E.tenella oocysts infection. Increase in cholesterol might be due to decrease billiary excretion of cholesterol in anorexia. Our results were in agreement with the observations of Singh et al., (1976), Padmavathi and Muralidharan (1986) and Basith et al., (2000). The hypercholesteremia observed in present study among the infected birds might be due to disturbed fat metabolism and loss of fluid resulting in apparent increase (Padmavathi and Muralitharan, 1986) or due to impaired liver function leads to disturbed fat metabolism consequent to injury to intestinal epithelium in coccidiosis (Basith et al., 2000).

\section{Effect on serum glutamic oxalo-acetic transaminase}

At 3 week of age SGOT value were about 3035 I.U higher in treatment group as compare to control birds. The post infection values (U/L) were significantly higher in $\mathrm{T} 1$ group
$(320.20 \pm 3.87)$ and T3 group $(314.60 \pm 5.24)$ among four treatment groups. Post infection value in control group was significantly higher $(314.80 \pm 4.52 \mathrm{U} / \mathrm{L})$ as compare with pre infection control $(240.60 \pm 2.94 \mathrm{U} / \mathrm{L})$. The result showed better efficacy of Salinomycin followed by Maduramicin as compared to Diclazuril and Diclazuril + Salinomycin group.

Rizvi et al., (2008) reported higher AST and ALT value in salinomysin 60-120 ppm given coccidiostat feed at 12 week of age in layer type birds similar to our findings. Significant increase in SGOT activity observed in coccidia affected birds under study might be due to damage to liver and intestine. Coles, (1986) and Montogomery et al., (1990) also reported SGOT increase due to cellular membrane and tissue degeneration.

\section{Effect on serum glutamic pyruvic transaminase}

At 3 week of age, SGPT values were in range of $36 \mathrm{U} / \mathrm{L}$ to $39 \mathrm{U} / \mathrm{L}$ between control and treatment groups which were not differing significantly. After experimental infection significant higher value were observed in $\mathrm{T} 1$ and $\mathrm{T} 2$ group as compare to pre infection. After infection, positive control bird showing significant higher value $(46.60 \pm 0.85 \mathrm{U} / \mathrm{L})$ as compared to pre infection value $(36.00 \pm 1.13$ $\mathrm{U} / \mathrm{L})$. Result indicated the effect of infection on SGPT value.

Among coccidiostat treatment used in experiments, Diclazuril and Salinomycin causing less pathogenic damage as compare to Maduramicin. Biu et al., (2006) also reported similar findings of increased ALT level in mixed coccidia infected chickens. Deger et al., (2002) also found comparable higher SGPT values in coccidia-affected birds before treatment of coccidiostats. 
Table.1 Biochemical value (Mean + S.E.) in different treatment group before and after experimental infection of E. tenella

\begin{tabular}{|c|c|c|c|c|c|c|c|c|c|c|c|c|}
\hline \multirow[t]{2}{*}{ Parameter } & \multirow{2}{*}{$\begin{array}{c}(\mathbf{B I} \\
\text { or } \\
\mathbf{A I})\end{array}$} & \multirow[t]{2}{*}{$\mathbf{T}_{1}$} & \multirow[t]{2}{*}{$\mathbf{T}_{2}$} & \multirow[t]{2}{*}{$\mathbf{T}_{\mathbf{3}}$} & \multirow[t]{2}{*}{$\mathbf{T}_{4}$} & \multirow[t]{2}{*}{$\mathbf{T}_{5}$} & \multirow[t]{2}{*}{$\mathbf{T}_{6}$} & \multirow{2}{*}{$\begin{array}{c}\text { Period } \\
\text { Mean }\end{array}$} & \multicolumn{2}{|c|}{$\mathbf{P}$} & \multicolumn{2}{|c|}{$\mathbf{T} \times \mathbf{P}$} \\
\hline & & & & & & & & & S Em & C.D. & S Em & C.D. \\
\hline \multirow[t]{2}{*}{$\begin{array}{l}\text { Serum Glucose } \\
\quad(\mathrm{mg} \%)\end{array}$} & BI & $\begin{array}{c}262.50 \\
\pm 3.44\end{array}$ & $\begin{array}{c}273.90 \\
\pm 2.73\end{array}$ & $\begin{array}{l}263.30 \\
\pm 60.26\end{array}$ & $\begin{array}{c}268.70 \\
\pm 3.11\end{array}$ & $\begin{array}{c}267.90 \\
\pm 2.58\end{array}$ & $\begin{array}{c}270.00 \\
\pm 2.70\end{array}$ & 267.72 & 1.18 & 3.32 & 2.90 & 8.13 \\
\hline & AI & $\begin{array}{c}237.40 \\
\pm 1.58\end{array}$ & $\begin{array}{c}210.40 \\
\pm 1.63\end{array}$ & $\begin{array}{c}238.40 \\
\pm 1.36\end{array}$ & $\begin{array}{l}224.20 \\
\pm 5.05\end{array}$ & $\begin{array}{c}203.60 \\
\pm 2.73\end{array}$ & $\begin{array}{c}270.00 \\
\pm 2.70\end{array}$ & 230.67 & & & & \\
\hline \multirow[t]{2}{*}{$\begin{array}{c}\text { Serum Total } \\
\text { Protein }(\text { gm \%) }\end{array}$} & BI & $\begin{array}{c}4.50 \\
\pm 0.11\end{array}$ & $\begin{array}{c}4.26 \\
\pm 0.09\end{array}$ & $\begin{array}{c}4.28 \\
\pm 0.15\end{array}$ & $\begin{array}{c}4.52 \\
\pm 0.10\end{array}$ & $\begin{array}{c}4.62 \\
\pm 0.06\end{array}$ & $\begin{array}{c}4.43 \\
\pm 0.10\end{array}$ & 4.44 & 0.04 & 0.10 & 0.09 & 0.25 \\
\hline & AI & $\begin{array}{c}3.58 \\
\pm 0.08\end{array}$ & $\begin{array}{c}3.75 \\
\pm 0.03\end{array}$ & $\begin{array}{l}3.62 \\
\pm 0.07\end{array}$ & $\begin{array}{c}3.46 \\
\pm 0.08\end{array}$ & $\begin{array}{c}3.28 \\
\pm 0.06\end{array}$ & $\begin{array}{c}4.49 \\
\pm 0.07\end{array}$ & 3.70 & & & & \\
\hline \multirow{2}{*}{$\begin{array}{c}\text { Serum Total } \\
\text { Cholesterol } \\
(\mathrm{mg} \%)\end{array}$} & BI & $\begin{array}{l}115.60 \\
\pm 2.93\end{array}$ & $\begin{array}{c}114.60 \\
\pm 2.78\end{array}$ & $\begin{array}{l}109.40 \\
\pm 2.50\end{array}$ & $\begin{array}{l}119.40 \\
\pm 1.19\end{array}$ & $\begin{array}{l}112.80 \\
\pm 2.37\end{array}$ & $\begin{array}{c}116.60 \\
\pm 2.48\end{array}$ & 114.73 & 0.94 & 2.64 & 2.31 & 6.46 \\
\hline & AI & $\begin{array}{l}121.60 \\
\pm 0.65\end{array}$ & $\begin{array}{c}130.50 \\
\pm 3.58\end{array}$ & $\begin{array}{c}131.90 \\
\pm 3.12\end{array}$ & $\begin{array}{c}122.00 \\
\pm 0.60\end{array}$ & $\begin{array}{c}142.50 \\
\pm 1.44\end{array}$ & $\begin{array}{l}115.20 \\
\pm 1.61\end{array}$ & 127.28 & & & & \\
\hline \multirow[t]{2}{*}{ SGOT (U/L) } & BI & $\begin{array}{l}276.60 \\
\pm 2.44\end{array}$ & $\begin{array}{l}271.80 \\
\pm 2.14\end{array}$ & $\begin{array}{l}276.20 \\
\pm 2.88\end{array}$ & $\begin{array}{l}274.80 \\
\pm 2.27\end{array}$ & $\begin{array}{l}240.60 \\
\pm 2.94\end{array}$ & $\begin{array}{c}239.80 \\
\pm 2.33\end{array}$ & 263.30 & 1.64 & 4.59 & 4.01 & 11.25 \\
\hline & AI & $\begin{array}{c}320.20 \\
\pm 3.87\end{array}$ & $\begin{array}{c}278.40 \\
\pm 5.92\end{array}$ & $\begin{array}{c}314.60 \\
\pm 5.24\end{array}$ & $\begin{array}{c}286.00 \\
\pm 7.13\end{array}$ & $\begin{array}{c}314.80 \\
\pm 4.52\end{array}$ & $\begin{array}{c}242.10 \\
\pm 2.52\end{array}$ & 292.68 & & & & \\
\hline \multirow[t]{2}{*}{ SGPT (U/L) } & BI & $\begin{array}{l}37.50 \\
\pm 0.83\end{array}$ & $\begin{array}{l}36.60 \\
\pm 0.95\end{array}$ & $\begin{array}{l}38.80 \\
\pm 0.68\end{array}$ & $\begin{array}{l}36.30 \\
\pm 1.01\end{array}$ & $\begin{array}{l}36.00 \\
\pm 1.13\end{array}$ & $\begin{array}{l}35.60 \\
\pm 0.76\end{array}$ & 36.80 & 0.51 & 1.42 & 1.24 & 3.48 \\
\hline & AI & $\begin{array}{l}42.00 \\
\pm 1.33\end{array}$ & $\begin{array}{l}41.20 \\
\pm 1.55\end{array}$ & $\begin{array}{l}40.80 \\
\pm 1.84\end{array}$ & $\begin{array}{l}38.80 \\
\pm 2.15\end{array}$ & $\begin{array}{l}46.60 \\
\pm 085\end{array}$ & $\begin{array}{l}36.60 \\
\pm 0.78\end{array}$ & 41.00 & & & & \\
\hline \multirow[t]{2}{*}{$\begin{array}{l}\mathbf{A K P} \\
(\mathbf{U} / \mathbf{L})\end{array}$} & $\mathrm{BI}$ & $\begin{array}{l}752.60 \\
\pm 4.47\end{array}$ & $\begin{array}{l}728.80 \\
\pm 5.71\end{array}$ & $\begin{array}{l}734.80 \\
\pm 6.70\end{array}$ & $\begin{array}{l}729.80 \\
\pm 5.01\end{array}$ & $\begin{array}{l}676.60 \\
\pm 4.42\end{array}$ & $\begin{array}{c}680.24 \\
\pm 4.37\end{array}$ & 717.14 & 2.91 & 8.17 & 7.14 & 20.01 \\
\hline & AI & $\begin{array}{l}759.80 \\
\pm 2.48\end{array}$ & $\begin{array}{l}751.00 \\
\pm 1.87\end{array}$ & $\begin{array}{l}760.80 \\
\pm 2.69\end{array}$ & $\begin{array}{l}750.00 \\
\pm 1.98\end{array}$ & $\begin{array}{l}896.35 \\
\pm 20.29\end{array}$ & $\begin{array}{c}679.20 \\
\pm 4.19\end{array}$ & 766.19 & & & & \\
\hline
\end{tabular}

The means bearing different superscript within same row differ significantly from each other $(\mathrm{P}<0.05)$

$\mathrm{BI}=$ Before Infection AI = After Infection 
Table.2 Biochemical value (Mean + S.E.) showing treatment mean in different treatment group

\begin{tabular}{|c|c|c|c|c|c|c|c|c|c|c|}
\hline \multirow[t]{2}{*}{ Parameter } & \multirow[t]{2}{*}{$T_{1}$} & \multirow[t]{2}{*}{$\mathbf{T}_{2}$} & \multirow[t]{2}{*}{$\mathbf{T}_{3}$} & \multirow[t]{2}{*}{$\mathbf{T}_{4}$} & \multirow[t]{2}{*}{$T_{5}$} & \multirow[t]{2}{*}{$T_{6}$} & \multicolumn{2}{|c|}{$\mathbf{T}$} & \multicolumn{2}{|c|}{$\mathbf{T} \times \mathbf{P}$} \\
\hline & & & & & & & $\begin{array}{c}\mathrm{S} \\
\mathrm{Em}\end{array}$ & C.D. & $\begin{array}{c}\mathrm{S} \\
\mathrm{Em}\end{array}$ & C.D. \\
\hline $\begin{array}{c}\text { Serum } \\
\text { Glucose (mg } \\
\%)\end{array}$ & $249.95^{b}$ & $242.15^{\mathrm{c}}$ & $250.85^{\mathrm{b}}$ & $246.45^{\mathrm{bc}}$ & $235.75^{\mathrm{d}}$ & $270.00^{\mathrm{a}}$ & 2.05 & 5.75 & 2.90 & 8.13 \\
\hline $\begin{array}{c}\text { Serum Total } \\
\text { Protein (gm } \\
\%)\end{array}$ & $4.04^{\mathrm{b}}$ & $4.01^{\mathrm{b}}$ & $3.95^{\mathrm{b}}$ & $3.99^{b}$ & $3.95^{\mathrm{b}}$ & $4.46^{\mathrm{a}}$ & 0.06 & 0.18 & 0.09 & 0.25 \\
\hline $\begin{array}{c}\text { Serum Total } \\
\text { Cholesterol } \\
(\mathrm{mg} \%)\end{array}$ & $118.60^{\mathrm{bc}}$ & $122.55^{b}$ & $120.65^{b}$ & $120.70^{\mathrm{b}}$ & $127.65^{\mathrm{a}}$ & $115.90^{c}$ & 1.63 & 4.57 & 2.31 & 6.46 \\
\hline SGOT (U/L) & $298.40^{\mathrm{a}}$ & $275.10^{b}$ & $295.40^{\mathrm{a}}$ & $280.40^{\mathrm{b}}$ & $277.70^{b}$ & $240.95^{c}$ & 2.84 & 7.96 & 4.01 & 11.25 \\
\hline SGPT (U/L) & $39.75^{\mathrm{ab}}$ & $38.90^{\mathrm{ab}}$ & $39.80^{\mathrm{ab}}$ & $37.55^{\mathrm{bc}}$ & $41.30^{\mathrm{a}}$ & $36.10^{\mathrm{c}}$ & 0.88 & 2.46 & 1.24 & 3.48 \\
\hline $\begin{array}{l}\text { AKP } \\
\text { (U/L) }\end{array}$ & $756.20^{b}$ & $739.90^{c}$ & $747.80^{\mathrm{bc}}$ & $739.90^{c}$ & $786.48^{\mathrm{a}}$ & $679.72^{d}$ & 5.05 & 14.15 & 7.14 & 20.01 \\
\hline
\end{tabular}

The means bearing different superscript within same row differ significantly from each other $(\mathrm{P}<0.05)$

Effect on Serum Alkaline Phosphatase: At 3 week of age AKP value were significant higher in all four treatment group as compare to control group. The highest value (U/L) was observed in $\mathrm{T} 1$ group $(752.60 \pm 4.47)$ followed by $\mathrm{T} 3$ group $(734.80 \pm 6.70)$, $\mathrm{T} 4$ group (729.80 \pm 5.01$)$ and T2 group (728.80 \pm 5.71) indicating better efficacy of Salinomycin and Maduramicin as compared with Diclazuril and Diclazuril + Salinomycin group. Post experimental infection of E.tenella causing less damage in birds given Diclazuril and Salinomycin as compare with other group. Significantly higher post infection AKP value $(896.35 \pm 20.29 \mathrm{U} / \mathrm{L})$ was observed as compared with pre infection $\mathrm{T} 5$ value $(676.60 \pm 4.42 \mathrm{U} / \mathrm{L})$.

Kogut and Powel (1993) stated that AKP activity may be the sensitive marker of the pathogenesis in coccidial infection of the caecum. Kalra et al., (1996) reported significant increase in serum AKP activity among infected birds. The present increase in serum AKP activity might be due to damage to liver, intestine and kidneys, which liberate the enzymes into the circulation (Kalra et al., 1996). The noticeably increased serum activities of AKP found in the present study might be associated with the metabolic alteration and damage of the bone marrow as compensation for the blood losses; the bone marrow might be forced to produce excessive blood cellular components as reported by Adamu et al., (2013). As a result of cellular damage several enzymes like ALT, AST and AP beach out into serum and hence their levels are increased depending upon the type and extent of damage (Hussain and Rahman, 2005).

\section{Acknowledgement}

The authors are highly thankful to Principal and Dean, College of Veterinary Science and A.H., Anand and Princial Scientist and Head, Poultry Complex, AAU, Anand for providing the necessary facilities. 


\section{References}

Adamu, M., Chaiwat, B., Nirat, G. and Montakan, V. (2013). Haematological, Biochemical and Histopathological Changes Caused by Coccidiosis in Chickens., Kasetsart. J. Nat. Sci., 47: $238-246$.

Allen, P. C. (1988). The effect of Eimeria acervulina infection on plasma lipids and lipoproteins in young broiler chicks. Vet. Parasitol., 30(1): 17-30.

Basith, Abdul S., Rajavelu, G. and Murali Manohar, B. (2000). Biochemical studies in experimental Eimeria necatrix infection in chickens., Indian Vet. J., 75: 876-878.

Chakarabarti Amalendu (1989): Practice of Poultry Medicine. New Delhi, India: Kalyani Publisher Ltd. pp.22-34.

Coles, E.H. (1986). Veterinary Pathology. $4^{\text {th }}$ Edn. W.B. Saunders, London.

Constantinescu, V. (1976). Biochemical and histoenzymic changes in coccidiosis in chickens. Buletinul Institutului Agronomic Cluj Napoca, 30: 115-117.

Conway, D. P., Sasai, K., Gaafar, S. M. and Smothers, C.D. (1993). Effects of different levels of oocyst inoculation of Eimeria acervulina, E. tenella and E. maxima on plasma constituents, packed cell volume, lesion scores and performance in chicken. Avian Dis., 37: 118-123.

Deger, Y., Dedo, S. and Deger, S. (2002). Enzyme activity changes in the sera of chickens treated with coccidiostatic agents. Indian Vet. J., 79: 912-916.

Hussein, M. S. and Abd-El-Rahman, A. H. (2005). Haematological, Biochemical, Immunological and Histopathological Changes Caused by Salinomycin in chicken. Egyptian J Natural Toxins, 2:13-38.

Kalra, C.S., Gill, B. S. and Singh, H. (1996). Serum biochemical studies on interaction of aflatoxicosis and coccidiosis in poultry. Indian Vet. J., 73: 504-508.

Kogut, M. H. and Powell, K. C. (1993). Preliminary findings of alterations in serum alkaline phosphatase activity in chickens during coccidial infections. J. Comp. Pathol., 108 (2): 113-119.

Mc Dougald, L. R. and Reid, W.M. (1991). In: Diseases of Poultry. Ninth Edn. Calnek, B.W., Johri Barnes, H., Beard, C.W. Reid, W.M. and Yoder, Jr. H.W (Eds), Wolfe Publishing Ltd, Iowa State University Press, Ames, Iowa, pp. 780-797.

Mondal, D. K., Chattopadhyay, S., Batabyal, S., Bera, A. K. and Bhattacharya, K., (2011). Plasma biochemical indices at various stages of infection with a field isolate of Eimeria tenella in broiler chicken Vet. World, 4(9):404-409.

Montgomery, R., Conway, T.W. and Spector, A.A. (1990). Biochemistry: A Case Oriented Approach. The S.C.V. Mosby Co., St. Louis.

Padmavathi, P. and Muralidharan, S. R. G., (1986). Studies on the alteration in the serum metabolites during the Eimeria tenella infection in chicks. Indian Vet. J., 63: 530-536.

Pangasa, A., Singala, L. D. and Asuma (2007). Biochemical alterations in chicken during Eimeria tenella infection medicated with coccidiostats and immunomodulator. Indian J. Field Veterinarian, 3(2):6-10.

Patra, G., Rajkhow, T. K., Ali, M.A., Tiwari, J.G. and Sailo, L. (2010). Studies on clinical, gross, histopathological and biochemical parameters in Broiler Birds suffered from Eimeria necatrix infection in Aizwal District of Mizoram, India. Int. J. Poul. Sci., 9(12):1120-1124.

Prabhakaran, R. (2012). Overview of poultry production in India vis- a-vis global 
scenario. XXIX Annual conference and national symposium of Indian poultry science association (IPSACON-2012) on Commercial and rural poultry production: Novel concepts and strategies to meet growing demand and changing consumer's needs on $5^{\text {th }}$ $-7^{\text {th }}$ December at Hyderabad. pp: 3-11.

Rizvi, F., Anjum, A. D., Khan, A., Mohsan, M. and Shazad, M. (2008). Pathological and Serum Biochemical Effects Of Salinomycin on Layer Chicks. Pakistan Vet. J., 28(2): 71-75.

Saima, M. Z., Jabbar, M. A., Mehmud, A., Abbas, M. M. and Mahmood, A. (2010). Effect of lysine supplementation in low protein diets on the performance of growing broilers. Pakistan Vet. J., 30: 17-20.

SAS. (2000). Statistical Analysis System. SAS Institute Inc. Cary, North Carolina, USA. 1028 pp.

Singh, C. V., Joshi, H. C. and Shah, H. I. (1976). Biochemical studies in intestinal coccidiosis of Poultry.
Pantnagar J. Res., 1: 63-66.

Singh, R. P. (2012). Present status and prospects of egg and poultry processing in India. XXIX Annual conference and national symposium of Indian poultry science association (IPSACON-2012) on Commercial and rural poultry production: Novel concepts and strategies to meet growing demand and changing consumer's needs on $5^{\text {th }}-7^{\text {th }}$ December at Hyderabad. pp: 111-115.

Snedecor, G. W. and Cochran, W. G. (1980). Statistical Methods. $8^{\text {th }}$ Ed. Iowa State Univ. Press, Ames. Iowa, USA.

Talebi, A., Asri-Rezaei, S., Rozeh-Chai R. and Sahraei, R.(2005). Comparative Studies on Haematological Values of Broiler Strains (Ross, Cobb, Arboracres and Arian). Intl. J. Poul. Sci. 4 (8): 573-579.

Williams, R. B. (1998). Epidemiological aspects of the use of live anticoccidial vaccine for chickens. Int. J. Parasitol., 28:1089-1098.

\section{How to cite this article:}

Hirani, N.D., J.J. Hasnani, S.S. Pandya and Madhira, S.P. 2018. Biochemical Changes in Induced Caecal Coccidiosis in Broiler Birds Given Different Feed Anticoccidials at Anand, Gujarat, India. Int.J.Curr.Microbiol.App.Sci. 7(07): 1044-1051. doi: https://doi.org/10.20546/ijcmas.2018.707.127 